Problems of World Agriculture volume 18 (XXXIII), number 4, 2018: 493-503 DOI: 10.22630/PRS.2018.18.4.137

\author{
Natalia Wasilewska $^{1}$, Mirosław Wasilewski ${ }^{2}$, Serhiy Zabolotnyy ${ }^{3}$ \\ ${ }^{1}$ Jan Kochanowski University in Kielce, Poland \\ ${ }^{2,3}$ Warsaw University of Life Sciences - SGGW, Poland

\section{The Enterprise's Financial Condition Assessment as a Component of its Creditworthiness}

\begin{abstract}
The article covers aspects of financial condition analysis regarding creditworthiness of Ukrainian agricultural enterprises that had to operate in unstable economic conditions in 2009-2017. It is proposed to improve methodological approaches to financial assessment of an enterprise - a potential borrower, due to changes in the economy, in particular in the financial sector, which have been influenced by crises that have shaken the Ukrainian economy twice in the past ten years. The proposed approaches to assessing the financial condition of an agricultural enterprise as a component of its creditworthiness increase the accuracy and credibility of such assessments and help to minimize credit risks
\end{abstract}

Key words: financial condition assessment, lending to enterprises, credit history, liquidity, debt, business activity, profitability

JEL Classification: G32

\title{
Introduction
}

This is the second of five articles describing research conducted to assess the creditworthiness of Ukrainian enterprises and the impact of such assessment on credit rates. Within the study, it was assumed that evaluation of credit worthiness of enterprises involves four factors, including: a credit history of a company (Wasilewska, Davydenko, 2017), its financial state, a business plan and adequacy of collateral. The article describes the results of financial condition assessments for enterprises.

In order for results of the study to be reasonable and credible, one should consider economic processes that took place in the Ukrainian economy from 2007 to 2017. The environment in which an enterprise operates in has a significant impact on its activities and financial performance. Financial results of Ukrainian companies versus inflation in Ukraine in 2001-2016 are shown in Table 1.

The first crisis that hit Ukraine in 2008 was a continuation of the global financial crisis that began in the USA. The impact of the initial financial shock on the Ukrainian economy was one of the most serious in European countries. The devaluation of the Ukrainian currency - hryvnia - reached 40\% during 2008-2009. Of course, neither enterprises, nor financial institutions (including banks) could react to such processes adequately.

\footnotetext{
${ }^{1}$ dr hab., prof. UJK, Department of Management, Jan Kochanowski University, e-mail: n.wasilewska@unipt.pl; https://orcid.org/0000-0001-8638-4735

${ }^{2} \mathrm{dr}$ hab., Department of Finance, Warsaw University of Life Sciences - SGGW, Nowoursynowska 166 St., e-mail: miroslaw_wasilewski@sggw.pl; https://orcid.org/0000-0001-6791-5713

${ }^{3} \mathrm{PhD}$, Department of Finance, Warsaw University of Life Sciences - SGGW, Nowoursynowska 166 St., e-mail:serhiy_zabolotnyy@sggw.pl,https://orcid.org/0000-0003-4701-0495
} 
494 N. Wasilewska, M. Wasilewski, S. Zabolotnyy

Table 1. Financial Performance of Ukrainian Enterprises versus Inflation

\begin{tabular}{|c|c|c|c|c|c|c|c|c|}
\hline Year & $\begin{array}{l}\text { Financial r } \\
\text { million, } \\
\text { UAH }\end{array}$ & $\begin{array}{l}\text { sult before tax } \\
\text { growth } \\
\text { rate/rate of } \\
\text { decrease, \% }\end{array}$ & $\begin{array}{c}\text { million, } \\
\text { UAH }\end{array}$ & $\begin{array}{c}\text { rate of } \\
\text { decrease, } \\
\%\end{array}$ & $\begin{array}{l}\text { million, } \\
\text { UAH }\end{array}$ & $\begin{array}{l}\text { growth } \\
\text { rate, } \%\end{array}$ & $\begin{array}{l}\text { Infla- } \\
\text { tion, } \\
\%\end{array}$ & $\begin{array}{c}\text { Accumulated } \\
\text { inflation, } \%\end{array}$ \\
\hline 2002 & 14641 & 78 & -22770 & 108 & 37411 & 94 & 99 & 105 \\
\hline 2003 & 19643 & 134 & -26174 & 115 & 45817 & 122 & 108 & 114 \\
\hline 2004 & 44578 & 227 & -29116 & 111 & 73695 & 161 & 112 & 128 \\
\hline 2005 & 64371 & 144 & -24794 & 85 & 89165 & 121 & 110 & 141 \\
\hline 2006 & 76253 & 118 & -34395 & 139 & 110649 & 124 & 112 & 158 \\
\hline 2007 & 135898 & 178 & -47097 & 137 & 182994 & 165 & 117 & 184 \\
\hline 2008 & 8954 & 7 & -184715 & 392 & 193669 & 106 & 122 & 225 \\
\hline 2009 & -42415 & -574 & -186474 & 101 & 144059 & 74 & 112 & 252 \\
\hline 2010 & 58334 & 238 & -153675 & 82 & 212009 & 147 & 109 & 175 \\
\hline 2011 & 122210 & 210 & -150516 & 98 & 272726 & 129 & 105 & 288 \\
\hline 2012 & 101885 & 83 & -176054 & 117 & 277939 & 102 & 100 & 287 \\
\hline 2013 & 29283 & 29 & -205231 & 117 & 234514 & 84 & 101 & 289 \\
\hline 2014 & -523587 & -1888 & -858104 & 418 & 334517 & 143 & 125 & 361 \\
\hline 2015 & -340100 & 65 & -815302 & 95 & 475202 & 142 & 143 & 517 \\
\hline 2016 & -22875 & 1587 & -547032 & 67 & 524175 & 111 & 114 & 590 \\
\hline
\end{tabular}

Source: Based on statistical data (Statistical Yearbook of Ukraine, 2017).

A new "era of losses" has started for Ukrainian enterprises, as financial results of most companies have turned negative since 2008. The enterprises have barely managed to recover and adapt to the new environment, when a new round of political instability and military actions struck in late 2013. Figure 1 clearly shows that 2008 and 2014 became the starting points for initiating new extremely negative processes for Ukrainian enterprises, resulting in substantial losses for the majority of enterprises.

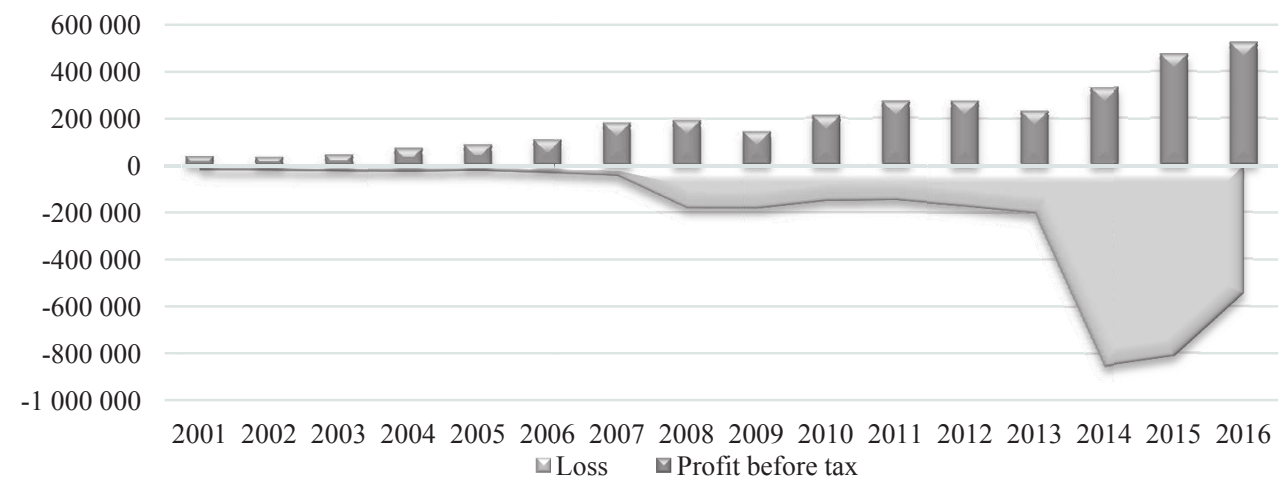

Fig. 1. Profit and loss of Ukrainian enterprises

Source: Based on statistical data (Statistical Yearbook of Ukraine, 2017). 
However, the economic situation in Ukraine has greatly worsened due to an extremely high rate of price growth over the past 10 years. Thus, during 2000-2016 the level of accumulated inflation reached $590 \%$. In Figure 2, an attempt was made to show profitability/loss of Ukrainian enterprises adjusted for inflation. After all, it is in this way that one can correctly evaluate financial performance of companies operating under conditions of high inflation. It should be noted that in 2015, profitability of enterprises was $1 \%$; however, given the inflation, the situation deteriorated significantly - estimated loss ratio of enterprises accounted for $43 \%$.

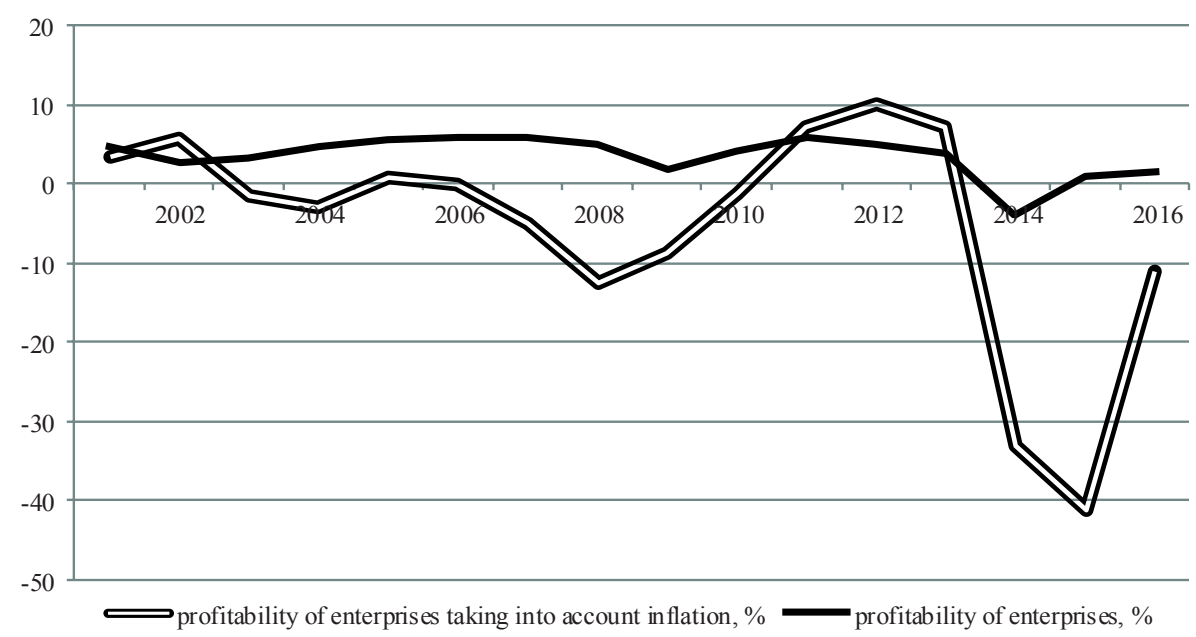

Fig. 2. Profitability of Ukrainian enterprises adjusted for inflation

Source: Based on statistical data (Statistical Yearbook of Ukraine, 2017).

In such circumstances, the attractiveness of enterprises as potential borrowers decreased. Moreover, some companies suffering losses already have loans and can hardly fulfill their financial obligations. Therefore, at a certain moment, the level of nonperforming loans reached $50 \%$.

It is under these conditions in Ukraine, in addition to a tough business environment, changeable investment climate and lagging efficiency of management, that one needs to carefully reconsider procedures of creditworthiness evaluation, with a particular stress on the financial condition of a potential borrower. Introduction of new financial assessment requirements will help to minimize credit risks and increase the efficiency of cooperation between banks and enterprises.

The purpose of the study is to identify the quantitative measure of correlation between the assessment of the financial condition of an enterprise, including agrarian conditions, and the level of credit repayment under the banking sector crisis, as well as to improve methodological approaches to such assessment.

To achieve this goal the following steps are planned within the framework of the conducted research:

1. To describe the method of enterprises' financial condition evaluation as part of the model for assessing a company's creditworthiness. 
2. To conduct assessment of 200 financial reports of Ukrainian enterprises which applied for a loan to a commercial bank in 2017.

3. To compare results of assessment of financial reports of Ukrainian enterprises which applied for a loan in 2009, using the proposed model of an enterprise creditworthiness evaluation.

4. To substantiate the results of conducted research in view of the situation of the Ukrainian economy, and on the basis of this, to suggest changes to the model of creditworthiness evaluation in the part of enterprises' financial condition assessment, which will lead to an increase in accuracy of such assessment.

\section{Literature review}

Feschijan D. found that the notion "creditworthiness" can be defined as a presumed ability to meet agreed deadlines related to repaying credit and interest, considering the vitality of a borrower. The repayment process should be based on income received from business operations of a borrower, without deteriorating the financial position of any of counterparts (Feschijan, 2008).

Analysis of creditworthiness involves preliminary study of factors and prerequisites which can adversely affect duly repayment of the credit. It is of high importance that bank specialists demonstrate a competent and conscientious approach to a borrower (Stoyanov, 2008).

In Western European literature on banking, prerequisites for creditworthiness are divided into personal and financial. Personal prerequisites are greatly dependent on business management, including the ability to respond quickly and adequately to a changing economic environment. Data about the financial and economic situation of a loan applicant are defined as financial prerequisites for creditworthiness. These include forecasts about expected development of an industry and a company, as well as a study on whether a loan can be repaid in accordance with terms and using revenue from activity of a potential borrower (Feschijan, 2008).

Analysis can be useful in observing trends in financial performance of a company and determining interdependence between factors which influence the financial success of a business entity (Stoyanov, Feschijan, 2008).

Regarding assessment of the financial condition of a company, historical data as well as current position does matter for a bank. However, it is extremely important to assess long-term financial stability of a business, since it is expected to meet financial obligations to a bank in future. Sorak L., Urošević S. noted that bank credit officers relied on ratio analysis of a credit applicant's business. A procedure for credit applicants required credit officers to ask certain questions to complete financial analysis. Financial report analysis performed by credit officers put emphasis on the ability to return a loan and minimize credit risk (Sorak, Urošević, 2014).

Conducting an enterprise's financial analysis, certain groups of financial indicators that characterize an enterprise from different perspectives are used. The main groups of financial indicators are as follows:

1.Operating performance or turnover ratios,

2. Profitability ratios,

3. Financial leverage or debt ratios, 
4. Liquidity or solvency ratios.

Performanceor turnover ratios are measures of success in managing company's assets. They reflect circulation of assets in the business process.

Financial efficiency is often measured by profitability ratios (Zabolotnyy, Wasilewski, 2018). Absolute profitability is defined as the difference between revenues and expenses. The absolute profitability is usually divided by another number, such as equity or turnover. A better view of company's profitability can be achieved by analysing longer periods, as profitability ratios usually depict short-term profitability (Niskanen and Niskanen, 2003). Briefly put, if business revenues exceed business expenses a company can be considered profitable (Salmi and Rekola-Nieminen, 2004).

According to textbooks in business analysis, excessive debt on a balance sheet implies distress and leads to a decrease of creditworthiness of a company (Wahlen, Baginski, Bradshaw, 2014). Hence, the debt-to-asset ratio is a strong predictor of the borrower's ability to repay the loan (Zech and Pederson, 2003).

Niskanen and Niskanen define liquidity as a company's ability to pay off short-term debts. Liquidity is usually measured by working capital. Net working capital can be calculated by subtracting short-term debt from current assets. The result of these calculations demonstrate the surplus of operating assets which can be easily transferred into cash to maintain current business processes (Niskanen and Niskanen, 2003).

\section{Methodological approaches}

The proposed method involves a financial condition assessment of an enterprise (industrial or agrarian) as a borrower of a long-term or short-term loan. The method is intended to be applied as a component of the mathematical model of an enterprise's creditworthiness, considering its credit history, quality of a proposed business plan (if necessary), and adequacy of collateral (Wasilewska, 2009).

The method was developed and applied in practice in 2009 on a sample of 100 loan cases of enterprises. In the framework of research, the proposed method is to be improved to assess financial condition and potential of companies, given the needs and challenges of the Ukrainian economy.

The essence of the proposed method is as follows: At first, key indicators of financial rating of an enterprise-borrower were determined. These indicators were divided into three groups (Wasilewska, 2009):

- collateral quality;

- business activity and profitability;

- liquidity and financial sustainability.

Normative values of indicators and their weights are given in Table 2. Groups of indicators are arranged in a certain order. Coefficients from different groups are related to each other and their hierarchy reflects the importance for creditors. For example, the third group of indicators has the most significant impact in evaluation of creditworthiness. Coefficients that are assigned to the second group are also determinants for the first group. Moreover, the first group includes coefficients, which influence the level of indicators of the second group. 
Table 2. Indicators of financial rating of an enterprise

\begin{tabular}{|c|c|c|c|c|}
\hline \multirow[t]{2}{*}{ Indicator } & \multirow{2}{*}{$\begin{array}{l}\text { Normative } \\
\text { value of the } \\
\text { indicator* }\end{array}$} & \multicolumn{3}{|c|}{$\begin{array}{c}\text { Weightsof the indicator in financial rating of an } \\
\text { enterprise }\end{array}$} \\
\hline & & total & long-term & short- term \\
\hline \multicolumn{5}{|l|}{ 1.Indicators of collateral quality } \\
\hline 1.1. Debt ratio & $\geq 0,5$ & 10 & 10 & 10 \\
\hline 1.2. The depreciation of fixed assets & $>0,5$ & 5 & 10 & $\mathrm{x}$ \\
\hline 1.3. Liquidity of current assets & $\geq 0,5 / \geq 0,8$ & 5 & $\mathrm{x}$ & 10 \\
\hline \multicolumn{5}{|l|}{$\begin{array}{l}\text { 2. Indicators of business activity and } \\
\text { profitability }\end{array}$} \\
\hline 2.1. Asset turnover & $\geq 0,5 / \geq 1,0$ & 5 & 5 & 5 \\
\hline 2.2. Return on Assets (ROA) & $\geq 0,1$ & 15 & 15 & 15 \\
\hline 2.3. Return on Sales (ROS) & $\geq 0,2 / \geq 0,1$ & 10 & 10 & 10 \\
\hline \multicolumn{5}{|l|}{ 3. Liquidity and sustainability indicators } \\
\hline 3.1. Coverage of short-term obligations & $\geq 1,0$ & 15 & $\mathrm{x}$ & 30 \\
\hline 3.2. Coverage of long-term obligations & $\geq 0,5$ & 15 & 30 & $\mathrm{x}$ \\
\hline 3.3. Provision of own funds & $\geq 0,5$ & 10 & 10 & 10 \\
\hline 3.4. Maneuverability of own funds & $\geq 0,5$ & 10 & 10 & 10 \\
\hline TOTAL & & $\mathrm{x}$ & 100 & 100 \\
\hline
\end{tabular}

*The normative values are indicated for agrarian enterprises.

Source: Wasilewska, 2009.

The above hierarchy of indicators can be presented by the inequality:

$$
\mathrm{f}_{1}<\mathrm{f}_{2}<\mathrm{f}_{3},
$$

where $\mathrm{f}_{\mathrm{i}}$-weight of indicators of the $\mathrm{i}$-j group.

Obviously, $\Sigma \mathrm{f}_{\mathrm{i}}=100$. The weight of individual indicators $\mathrm{f}_{\mathrm{ij}}$ are defined as follows: $\min$ - 5; med - 10; max - 15. The corresponding weights of groups of indicators are differentiated within the limits: $20<\mathrm{f}_{\mathrm{i}}<50$.

Since C 1.1 shows the enterprise's equity capital provision, and C 1.2 and $C 1.3$ - the capital state, then: $\mathrm{f} 1.1=\mathrm{f} 1.2+\mathrm{f} 1.3$ at $\mathrm{f} 1.2=\mathrm{f} 1.3$.

Among the indicators of the 2nd group C 2.2 is the most important; indicators C 2.1 and $\mathrm{C} 2.3$ complement each other and the most important of them is $\mathrm{C} 2.3$. Therefore: $\mathrm{f} 2.2$ $=\mathrm{f} 2.1+\mathrm{f} 2.3$ at $\mathrm{f} 2.1<\mathrm{f} 2.3$. The most important indicators of the 3rd group are $\mathrm{C} 3.1$ and C 3.2. Herewith: $\mathrm{f} 3.1=\mathrm{f} 3.2$ and $\mathrm{f} 3.3=\mathrm{f} 3.4$ at f $3.3<\mathrm{f} 3.1$. Therefore $\mathrm{f} 1.1=10 ; \mathrm{f} 1.2=$ 5 ; f $1.3=5$; f $2.1=5$; f $2.2=15$; f $2.3=10$; f $3.1=15$; f $3.2=15$; f $3.3=10$; f $3.4=10$ Thus f $1=20 ; \mathrm{f} 2=30 ; \mathrm{f} 3=50$.

The class of the enterprise - borrower is determined by its financial rating, calculated in points based on values and weights of indicators (Table 3) (Wasilewska, 2009).

Then the aggregate value of an indicator is calculated according to the formula:

$$
P_{G}=\sum_{i=1}^{n} P_{i},
$$

where: $\mathrm{P}_{\mathrm{G}}$ - the aggregate measure of financial rating, $\mathrm{P}_{\mathrm{i}}-$ weighted value of an indicator.

Table 3. Definition of the borrower's class depending on its financial rating

\begin{tabular}{c|cc}
\hline № & Rating, points & Class \\
\hline 1 & $\geq 90$ & $\mathrm{~A}$ \\
2 & $80-89,9$ & $\mathrm{~B}$ \\
3 & $60-79,9$ & $\mathrm{C}$ \\
4 & $50-59,9$ & $\mathrm{D}$ \\
5 & $<50$ & $\mathrm{E}$ \\
\hline \multicolumn{2}{c}{ Source: Wasilewska, 2009. }
\end{tabular}


It is worth noting that the enterprises, which belong to classes $\mathrm{A}, \mathrm{B}$, or $\mathrm{C}$, have a satisfactory financial condition and can be credited by banks. The enterprises falling to D class can get a loan but the bank must obtain the sufficient guarantees to minimize credit risk. Enterprises that belong to the E class may not be credited at all.

Table 4. Consolidated balance sheet of the LLC "Agrosvit" and LLC "Servis" as of July 01, 2017, thousand UAH

\begin{tabular}{|c|c|c|c|c|}
\hline \multirow[b]{2}{*}{ Assets } & \multicolumn{2}{|c|}{ LLC “Agrosvit" } & \multicolumn{2}{|c|}{ LLC "Servis" } \\
\hline & $\begin{array}{c}\text { at the beginning of } \\
\text { the reporting } \\
\text { period }\end{array}$ & $\begin{array}{l}\text { at the end of the } \\
\text { reporting period }\end{array}$ & $\begin{array}{c}\text { at the beginning of } \\
\text { the reporting } \\
\text { period }\end{array}$ & $\begin{array}{l}\text { at the end of } \\
\text { the reporting } \\
\text { period }\end{array}$ \\
\hline I. Fixed assets & & & & \\
\hline In-progress capital investments & 550000 & 850000 & 173453 & 814453 \\
\hline Fixed assets & 2399583 & 3368447 & 2555845 & 2000394 \\
\hline initial value & 4152014 & 5160398 & 5232254 & 5757515 \\
\hline Accumulated depreciation & 1752431 & 1791951 & 2676409 & 3757121 \\
\hline Investment property & 82293 & 79300 & & \\
\hline Long-term financial investments: & 93884 & 90399 & & \\
\hline $\begin{array}{l}\text { which are accounted for using the equity } \\
\text { method of other enterprises }\end{array}$ & 93884 & 90399 & & \\
\hline Long-term receivables & & & 62445 & 85224 \\
\hline Total for Section I & 3125760 & 4388146 & 2791743 & 2900071 \\
\hline II. Current assets & & & & \\
\hline Inventory & 1933225 & 1965542 & 2195501 & 1587579 \\
\hline $\begin{array}{l}\text { Accounts receivable for products, goods, } \\
\text { works, services }\end{array}$ & 312866 & 395726 & 548821 & 482335 \\
\hline Cash and its equivalents & 323577 & 264475 & 444218 & 245350 \\
\hline Prepaid expenses & 132395 & 198502 & 480968 & 602000 \\
\hline Other current assets & & & 54882 & 45414 \\
\hline Total for Section II & 2702063 & 2824245 & 3724390 & 2962678 \\
\hline Balance & 5827823 & 7212391 & 6516133 & 5862749 \\
\hline Shareholder equity and liabilities & $\begin{array}{c}\text { at the beginning of } \\
\text { the reporting } \\
\text { period }\end{array}$ & $\begin{array}{l}\text { at the end of the } \\
\text { reporting period }\end{array}$ & $\begin{array}{c}\text { at the beginning of } \\
\text { the reporting } \\
\text { period }\end{array}$ & $\begin{array}{l}\text { at the end of } \\
\text { the reporting } \\
\text { period }\end{array}$ \\
\hline I. Equity capital & & & & \\
\hline Registered (share) capital & 2900000 & 2700000 & 2300000 & 3000000 \\
\hline Retained earnings (uncovered loss) & 1304936 & 1710924 & 756623 & 124 \\
\hline Total for Section I & 4204936 & 4410924 & 3056623 & 3000124 \\
\hline II. Long-term commitments and collateral & & & & \\
\hline Long-term bank credits & 200085 & 1194438 & 367735 & 0 \\
\hline Other long-term liabilities & 12435 & 35562 & 32265 & 54564 \\
\hline Total for Section II & 212520 & 1230000 & 400000 & 54564 \\
\hline III. Current liabilities and collateral & & & & \\
\hline Short-term bank credits & 335102 & 0 & 249017 & 1200000 \\
\hline Current payables for: & & & & \\
\hline Accounts payable & 269651 & 565022 & 1019208 & 193436 \\
\hline Wages and salaries & 405350 & 493978 & 844510 & 692115 \\
\hline Other current liabilities & 400264 & 512467 & 946775 & 722510 \\
\hline Total for Section III & 1410367 & 1571467 & 3059510 & 2808061 \\
\hline Balance & 5827823 & 7212391 & 6516133 & 5862749 \\
\hline
\end{tabular}

Source: Authors' own research. 


\section{Results and prospects of further research}

The procedure for applying the described method is illustrated by the following example. Commercial Bank "Inconbank" ${ }^{4}$ received one request from the LLC "Agrosvit" for a loan of 7,500 thousand UAH for a term of 28 months for reconstruction of the dairy plant production line. Another request was obtained from LLC "Servis" for a loan of 14,000 thousand UAH for a period of 30 months for construction of a service automobile center. The financial condition of the LLC "Servis" will be evaluated by using a procedure for the industrial enterprise, applying for a long-term loan. At the same time LLC "Agrosvit" will be assessed according to the standards for an agrarian enterprise - a potential recipient of long-term financing. Information from balance sheets of potential borrowers is presented in Table 4.

Not only information from the balance sheet of the enterprise is required for the financial state assessment, but also information from the profit and loss statement (Table 5).

Table 5. Selected information from consolidated profit and loss statement of the LLC "Agrosvit" and LLC "Servis" as of July 1, 2017, thousand UAH

\begin{tabular}{|c|c|c|c|c|}
\hline \multirow[b]{2}{*}{ Article } & \multicolumn{2}{|c|}{ LLC “SERVIS” } & \multicolumn{2}{|c|}{ LLC “Agrosvit” } \\
\hline & $\begin{array}{c}\text { for the previous } \\
\text { period }\end{array}$ & $\begin{array}{c}\text { for the reporting } \\
\text { period }\end{array}$ & $\begin{array}{c}\text { for the previous } \\
\text { period }\end{array}$ & $\begin{array}{c}\text { for the reporting } \\
\text { period }\end{array}$ \\
\hline $\begin{array}{l}\text { Revenue from sales of products, } \\
\text { goods, works, services } \\
\text { Net: }\end{array}$ & 6309650 & 10449370 & 6122458 & 8255423 \\
\hline Profit & 1304936 & 1710924 & 756623 & \\
\hline $\begin{array}{l}\text { Loss } \\
\text { II OPERATING EXPENSES }\end{array}$ & & & & 124 \\
\hline Depreciation & 58344 & 64256 & 75622 & 85231 \\
\hline
\end{tabular}

Source: Authors' own research.

The results of the two enterprises' financial condition assessment are presented in Table 6.

Table 6. The results of financial condition assessment of enterprises

\begin{tabular}{|c|c|c|c|c|c|}
\hline \multirow{2}{*}{ \#\# } & \multicolumn{2}{|c|}{ Indicators (cofficients) value } & \multirow{2}{*}{ \#\# } & \multicolumn{2}{|c|}{ Indicators (cofficients) in points } \\
\hline & LLCServis & LLCAgrosvit & & LLCServis & LLCAgrosvit \\
\hline $\mathrm{C}_{1.1}$ & 8,2 & 9,8 & $\mathrm{P}_{1.1}$ & 8,3 & 9,8 \\
\hline $\mathrm{C}_{1.2}$ & 5,6 & 10,4 & $\mathrm{P}_{1.2}$ & 5,7 & 10,0 \\
\hline $\mathrm{C}_{2.1}$ & 9,0 & 1,3 & $\mathrm{P}_{2.1}$ & 5,0 & 1,3 \\
\hline $\mathrm{C}_{2.2}$ & 5,0 & 5,8 & $\mathrm{P}_{2.2}$ & 5,0 & 5,0 \\
\hline $\mathrm{C}_{2.3}$ & 0,0 & 28,5 & $\mathrm{P}_{2.3}$ & 0,0 & 15,0 \\
\hline $\mathrm{C}_{3.1}$ & 0,0 & 13,1 & $\mathrm{P}_{3.1}$ & 0,0 & 10,0 \\
\hline $\mathrm{C}_{3.2}$ & 9,5 & 14,3 & $\mathrm{P}_{3.2}$ & 9,7 & 14,3 \\
\hline $\mathrm{C}_{3.3}$ & 25,0 & 69,3 & $\mathrm{P}_{3.3}$ & 25,1 & 30,0 \\
\hline $\mathrm{C}_{3.4}$ & 0,6 & 0,1 & $\mathrm{P}_{3.4}$ & 0,6 & 0,1 \\
\hline Total & $\mathrm{x}$ & $\mathrm{x}$ & Total & 60,0 & 95,6 \\
\hline
\end{tabular}

Source: Authors' own research.

Thus, the general assessment of the financial condition of the LLC "Agrosvit" is $P_{G}=\sum_{i=1}^{8} P_{i}=95.6$ points. However, the general assessment of the financial condition of

\footnotetext{
${ }^{4}$ The names of legal entities have been changed.
} 
the LLC "Servis" $\sum_{i=1}^{8} P_{i}=60.0$ points, which is extremely low. According to the proposed method, enterprises with 60 points can receive a loan, considering other components of creditworthiness at a satisfactory level.

Comparison of financial conditions of enterprises under the credit cases using correlation-regression analysis revealed a close relationship between these variables. As a result of the processing the following system of equations is compiled:

$\| \begin{aligned} & 11315=200 a+15739 b \\ & 976134=15739 a+1294812 b\end{aligned}||$

As a result of the system solution, the dependence is determined:

$$
\bar{y}_{x}=1,5264 \mathrm{x}-63,45 \leq 100,
$$

where $\bar{y}_{x}$ - the theoretical (most probable) level of credit obligations fulfillment by borrowers depending on the assessment of their financial condition, $\%$;

$\mathrm{x}$ - assessment of the financial condition of the borrower, points.

Coefficient of pair correlation $\mathrm{ry} / \mathrm{x}=0,836$.

The results of the study in 2017 based on 200 credit cases, showed a really threatening situation for cooperation between banks and enterprises. Even with an "ideal" financial condition of the enterprise with 100 points, the credit repayment level is $89 \%$, which indicates an extremely high level of credit risk. When the financial condition of the enterprise is assessed lower than 81 points, the credit risk exceeds the permissible level, which means that the bank should refuse to lend to the enterprise.

It is appropriate to recall the study results of 2009.The statistical processing of 100 credit cases made it possible to compile the following system of equations:

$$
\| \begin{aligned}
& 9600=100 a+7343 b \\
& 729434=7343 a+571625 b
\end{aligned}
$$

As a result of the system solution, the dependence is determined:

$$
\bar{y}_{x}=40,5104-0,75568 x \leq 100,
$$

The pair correlation coefficient was $r_{y / x}=0,70885$. With the financial condition assessment at 78,7 points and more - the credit risk was minimized, and in the case of a reduction to 60 points, the expected level of obligations performance fell to $85,8 \%$ (Wasilewska, 2009).

\section{Conclusions}

A comparison of the results of a financial condition assessment within 300 cases of Ukrainian companies applying for a bank credit in 2009 and 2017 makes it possible to formulate the following conclusions:

1. There is a significant decrease in the level of repayment of the loan (the level of repayment of the loan in the investigated bank: $2009-96.00 \%, 2017-56,58 \%$ ). Unfortunately, this situation is common for the entire banking sector in Ukraine. According 
to the National Bank of Ukraine, the level of non-repayment of loans in general for commercial banks in 2017 is more than 50\% (Wasilewska, Davydenko, 2017).

2. The complexity of the relationship between the studied variables, namely, the financial condition and the level of repayment of credit by calculating the correlation coefficient, has changed in the direction of increase for the last 8 years $\left(r_{y / x}=0,709\right.$ in 2009 and $r_{y / x}=0,836$ in 2017). However, even when the financial condition of the enterprise is estimated at 100 points, the level of credit repayment is only $89 \%$ in 2017, while in 2009 it was sufficient that the financial condition to be estimated at 78,7 points as the credit risk was minimized. To that end, one can draw the following conclusion: the significance of the financial condition in the overall assessment of creditworthiness has increased, but even an excellent financial condition cannot guarantee $100 \%$ financial obligations fulfillment. This fact can be explained by the extremely unstable economic situation in the country, which threatens even the financially strong enterprises.

3. The study also confirms the necessity of introducing changes to the methodological approach of assessing the financial condition of an enterprise. In our opinion, neither financial ratios, nor their construction, require any changes, since they sufficiently evaluate the financial state of an enterprise. The only matter that needs to be reviewed are the terms of the loan under the borrower's financial rating. Given the increased risk of borrowers' credit default, Ukrainian banks should review criteria on loangranting for enterprises from $\mathrm{C}$ or D class, including such parameters as the capacity of mortgage (real estate, which is securing financial obligations), risk premium credit rates ${ }^{5}$ or credit limits for enterprises. The introduction of such a system of measures is extremely necessary for the banks to maintain their liquidity under unstable economic conditions.

At the same time, an even more complicated situation occurs in relation to agrarian enterprises. In 2017 agrarian enterprises received loans for only $4 \%$ of the total requirement. The high risk level is inherent in agriculture, and thus predetermines a higher level of credit rates in relation to other sectors of the economy. This prevents lending in agribusiness. Thus, the beginning of 2018 turned out to be difficult both for Ukrainian businesses and the banking sector. Based on the unstable economic situation, banking institutions in Ukraine have to raise credit rates for long-term credits in national currency up to $30 \%$ per annum. Undoubtedly, the state policy support in the agrarian sector, in particular preferential credits, improves the situation to some extent.

3. Further research on assessment of creditworthiness of an enterprise in the context of its business performance and securitization plan is required. This will enable to develop an advanced multifactor model for assessing creditworthiness of an enterprise.

\section{References}

Bartram, S., Brown, G., Waller, W. (2015). How Important Is Financial Risk? Journal of Financial and Quantitative Analysis, 50(4), 801-824.

Bunyasi, G.N., Bwisa, H., Namusonge, G. (2014). Effects of entrepreneurial finance on growth of small and medium enterprises in Kenya. European Journal of Business and Management, 6(31), 113-123.

Feschijan, D. (2008). Analysis of the creditworthiness of bank loan applicants. Facta Universitatis. Series: Economics and Organization, 5(3), 273-280.

\footnotetext{
${ }^{5}$ It should be noted that this is not the best option since the level of credit rates is extremely high.
} 
Kruchok, N. (Wasilewska N.) (2009). Enterprise's Financial Assessment as credit borrower. Journal of National Bank of Ukraine, 20-23.

Ukraine in figures (2016). Statistical Yearbook of Ukraine. Edited by I. E. Werner. Kiev. State Statistics Service of Ukraine, 2017

Niskanen, J., Niskanen, M. (2004). Financial Analysis. 1st ed. Helsinki: Edita Prima Oy.

Saldana, J., Leavy, P. and Beretvas, N. (2011). Understanding Statistics: Fundamentals of Qualitative Research. 1st ed. Oxford University Press, USA. Available 13.3.2017 from: http://site.ebrary.com.lillukka.samk.fi/ lib/samk/detail.action?docID=10446255.

Salmi, I. and Rekola-Nieminen, L. (2004). Construction and interpretation of financial statements. 2nd ed. Helsinki: Edita Publishing Oy.

Sorak, L., Urošević, S. (2014). Use of financial indicators in the creditworthiness. Economics Management Information Technology, 2(4), 194-201.

Stoyanov, St. (2008). Credit Risk Analysis and Information Supply, S.

Wahlen, J.M., Baginski, S.P., Bradshaw, M.T. (2014). Financial Reporting, Financial Statement Analysis, and Valuation: A Strategic Perspective. Mason, OH: South-Western Cengage Learning.

Wasilewska, N., Davydenko, N. (2017). Assessment of the credit history of enterprises. Zeszyty Naukowe Polityki Europejskie, Finanse i Marketing, 18(67), 229-239.

Zabolotnyy, S., Wasilewski, M. (2018). Efficiency versus value of joint-stock companies from agribusiness sector of the Warsaw Stock Exchange - a perspective towards trade-off decisions, Bioeconomy : finance and taxes : home economics: new dimensions in the development of society : proceedings of the International Scientific Conference, 9-11 May 2018, Jelgava, Latvia / [ed. Anita Auzina], 187-195.

Zech, L., Pederson, G. (2003). Predictors of Farm Performance and Repayment Ability as Factors for Use in RiskRating Models. Agricultural Finance Review, 63(1), 41-54.

Zenzerović, R. (2011). Credit scoring models in estimating the creditworthiness of small and medium and big enterprises. Croatian Operational Research Review (CRORR), 2, 143-157.

\section{For citation:}

Wasilewska N., Wasilewski M., Zabolotnyy S. (2018). The Enterprise's Financial Condition Assessment as a Component of its Creditworthiness. Problems of World Agriculture, 18(4), 493-503; DOI: $10.22630 /$ PRS.2018.18.4.137 